\title{
Prevalência de helmintos em Canis familiaris (Linnaeus, 1758) no Hospital de Clínicas Veterinárias do Rio Grande do Sul através de diagnóstico post-mortem*
}

\author{
CRISTINE DOSSIN BASTOS FISCHER
}

Elinor Fortes (Orientadora - UFRGS)

Banca: Flávio A. P. Araújo (UFRGS), José M. Wiest (UFRGS), Nara A. R. Farias (UFPel)

Nesta pesquisa investigou-se a prevalência de helmintos em 51 cães provenientes da rotina clínica e cirúrgica do Hospital de Clínicas Veterinárias da Universidade Federal do Rio Grande do Sul (HCV-UFRGS) através de diagnóstico post-mortem durante os anos de 1998 a 2000. Do total de animais examinados, 72,5\% estavam infectados por uma ou mais espécies de helmintos intestinais, sendo que a infecção múltipla foi mais comumente observada (76,32\%). Assinalou-se a presença de quatro espécies de helmintos intestinais, descritas em ordem decrescente de prevalência: Ancylostoma caninum (Ercolani, 1859) 53\%, Dipylidium caninum (Limnaeus, 1758) 47\%, Trichuris vulpis (Froelich, 1789) 39,2\% e Toxocara canis (Werner, 1782) 19,6\%. Não foram observados helmintos nos demais órgãos examinados. Nos exames parasitológicos de fezes realizados pelo Método de Willis-Mollay identificou-se a presença de ovos de helmintos intestinais em $51 \%$ das amostras. Através dos resultados evidenciou-se uma associação positiva entre a presença de ovos dos nematódeos das espécies A. caninum e T. vulpis nas fezes e a presença destes nematódeos adultos no intestino delgado dos cães. A prevalência de alguns helmintos como T. canis e T. vulpis foi afetada pela idade dos animais, sendo que T. canis foi mais freqüente em cães com idade inferior a um ano e T. vulpis em cães com mais de cinco anos de idade. Além destes resultados, nesta pesquisa foi aplicado um questionário a 89 clínicos veterinários de pequenos animais de Porto Alegre. A conduta dos clínicos em relação à profilaxia e ao tratamento da helmintose intestinal canina foi consultada. Os resultados evidenciaram que os clínicos veterinários devem rever sua conduta clínica em relação a helmintose intestinal canina. Do total de veterinários entrevistados, $60,4 \%$ indicam o primeiro tratamento anti-helmíntico para filhotes com idade acima de três semanas, 34,8\% deles não discutem com os clientes assuntos relacionados a medidas higiênico-sanitárias e hábitos de defecação dos animais e 31,5\% não orientam os clientes sobre a importância da verminose canina em relação as zoonoses. Uma minoria de 39,3\% dos clínicos lembrou do potencial zoonótico do parasito T. canis responsável pela larva migrans visceral. A helmintose intestinal canina é uma realidade no HCV-UFRGS e programas de educação continuada devem ser realizados com os veterinários que trabalham nesta Instituição e em toda cidade de Porto Alegre, RS, para que helmintos comuns e perigosos, do ponto de vista de saúde pública, possam ser manejados através de medidas profiláticas simples e ao alcance de todos.

Descritores: parasitologia veterinária, helmintos, cães, diagnóstico post-mortem.

Apresentada: 25 janeiro 2001

\footnotetext{
"Dissertação de Mestrado n. 297 (Especialidade: Parasitologia). 65f. Programa de Pós-Graduação em Ciências Veterinárias, Faculdade de Veterinária de Porto Alegre - UFRGS. CORRESPONDÊNCIA: C.D.B. Fischer [e-mail: tinevet@terra.com.br].
} 


\title{
Prevalence of helminths in Canisfamiliaris (Linnaeus, 1758) at the Veterinary Hospital of Rio Grande do Sul**
}

\author{
CRISTINE DOSSIN BASTOS FISCHER
}

Elinor Fortes (Adviser - UFRGS)

Committee: Flávio A. P. Araújo (UFRGS), José M. Wiest (UFRGS), Nara A. R. Farias (UFPel)

In this survey it was investigated through post-mortem examination the prevalence of helminths in 51 dogs which were obtained from the Veterinary Hospital of the Federal University of Rio Grande do Sul during the years of 1998 and 2000. From the total of animals examinated $72.5 \%$ were infected with one or more intestinal helminths species and the multiple infeccions were more commonly observed (76.32\%). It was assigned the presence of four helminth species, described in decreasing prevalence order: Ancylostoma caninum (Ercolani, 1859) 53\%, Dipylidium caninum (Linneo, 1758) 47\%, Trichuris vulpis (Froelich, 1789) 39.2\% and Toxocara canis (Werner, 1782) 19.6\%. In the coprological exams through Willis-Mollay method it was identified intestinal helminth eggs in $51 \%$ of the fecal specimens. It was noticed a positive association between A. caninum and T. vulpis eggs found in feces and the presence of these adult worms in the dogs intestinal tract. The prevalence of some helminths as T. canis and T. vulpis was affected by the age of the animals. T. canis was more frequent in dogs less than one year old and T. vulpis, in dogs over five years old. Besides these results, it was conducted a survey to 89 small animal practicing veterinarians in Porto Alegre. The current veterinary practices concerning prophylaxis and treatment of canine intestinal helmintosis were consulted. The results showed the practicing veterinarians must review their practices concerning the canine intestinal helmintosis. From the total of interviewed veterinarians $60.4 \%$ recommend puppies to receive the first deworming treatment after 3 weeks of age, $34.8 \%$ of them don't discusse with their clients issues related to hygienic and sanitary measures and $31.5 \%$ don't inform their clients about canine worms and the related zoonosis. A minority of $39.3 \%$ remembered $T$. canis potential zoonotis risk, wich is responsible for larva migrans visceral. The canine intestinal helmintosis is a reality in HCV-UFRGS and continuing education programs should be done with the veterinarians who work in this institution and in the whole Porto Alegre city, for common and dangerous helminths, in a public health view, could be managed through simple profilatic measures, which everyone can use. These measures are summarized into four goals which are the elimination of the parasite infection from dogs, the prevention of dogs defecation in public areas, the promotion of campaigns about responsible pet ownership and education of the public about the potential zoonotic intestinal helminths. This work is certainly of veterinary resposibitlity.

Key words: veterinary parasitology, helminths, dogs, post-mortem diagnostic.

\footnotetext{
**Master's Thesis no.297 (Field: Parasitology). 65p. Postgraduate Program in Veterinary Sciences, Faculdade de Veterinária de Porto Alegre, Universidade Federal do Rio Grande do Sul (UFRGS) - Brazil. CORRESPONDENCE: C.D.B. Fischer [e-mail: tinevet@terra.com.br].
} 